\title{
Imobilization of trypsin in films of PVA/CGP
}

\author{
Bruna Moreira, Karla Batista, Kátia Fernandes \\ From 5th Congress of the Brazilian Biotechnology Society (SBBIOTEC) \\ Florianópolis, Brazil. 10-14 November 2013
}

\section{Background}

Trypsin is an enzyme widely used for digestion of peptides in proteomic research. However, this enzyme is one of the least stable of the neutral proteases and presents rapid autolysis, which causes a decrease in catalytic efficiency and a consequential increase in costs of biotechnological process. Immobilization of the enzyme offers the advantages of enhanced stability, protection against autolysis and the possibility of repeated use of the catalytic material. In addition, the preparation of a successfully immobilized enzyme depends very much on the method of immobilization employed and on the chemical characteristics of the support [1,2]. In this sense, a biodegradable film produced by blending polyvinyl alcohol (PVA) and cashew gum polysaccharides (CGP) was tested as support for trypsin immobilization.

\section{Methods}

The blends used in this sense were produced using the methodology described by Silva et.al (2013) [3]. The method chooses for immobilization was covalent linking and the hydrolytic activity of PVA/CGP/Trypsin film $(\mathrm{cm} 2)$ was assayed using benzoil-DL-arginina-p-nitroanilida (BapNa) as substrate. The results were analyzed using the software Statistica 7.0 (StatSoft Inc., Tulsa, OK, USA).One unit (UE) of enzyme activity was defined as the amount of enzyme that produces increase of 0,1 on absorbance. The PVA/CGP/Trypsin was tested repeatedly for hydrolysis of $\mathrm{BapNa}$, because this parameter it is important in continuous use reactor for bioconversion processes. For this the PVA/CGP /Trypsin films were stored in different conditions e tested your activity at each week.

Departamento de Bioquímica e Biologia Molecular, Laboratório de Química de Proteínas, Universidade Federal de Goiás, Cx. Postal 131, 74001-970, Goiânia, GO, Brazil

\section{Results and conclusions}

Multivariate analysis results showed that all factors significantly $(\mathrm{P}<0.05)$ affected the activity, and that factor interaction between time and temperature had no effect $(\mathrm{P}>0.05)$ on this response. The linear factors time and temperature positively affected response, and the linear term $\mathrm{pH}$ negatively affected the activity. The response surface showed a maximum region corresponding to at $25^{\circ} \mathrm{C}, \mathrm{pH} 4,0$ and 60 minutes corresponding to 4,79UE.

The regression analysis showed an adequate fit $\left(\mathrm{r}^{2}=0\right.$, 95) of experimental values to the second-order polynomial model as a function of significant factors. The mathematical model is represented in the following equation:

$$
\begin{aligned}
\mathrm{Y}= & -0,11+0,046 \mathrm{X}_{1}+0,004 \mathrm{X}_{2}+0,0002 \mathrm{X}_{2}{ }_{2}+0,003 \mathrm{X}_{3} \\
& +0,0001 \mathrm{X}^{2}{ }_{3}-0,002 \mathrm{X}_{1} \mathrm{X}_{2}+0,001 \mathrm{X}_{1} \mathrm{X}_{3}-0,0001 \mathrm{X}_{2} \mathrm{X}_{3},
\end{aligned}
$$

where, $\mathrm{Y}, \mathrm{X}_{1}, \mathrm{X}_{2}$ and $\mathrm{X}_{3}$ denoted absorbance at 405 $\mathrm{nm}, \mathrm{pH}$, time and temperature, respectively. The high operational stability of PVA/Chitosan/Trypsin film was a characteristic that indicates in this sense, showing stable for about three weeks at different storage conditions, leading to the believe that the immobilization process gives a better stability for the enzyme reaction when compared to the free enzyme.

\section{Acknowledgements \\ This work was supported by the Brazilian Ministry of Science and \\ Technology through CNPq.}

Published: 1 October 2014

\section{References}

1. Batista KA, Lopes FM, Yamashita F, Fernandes KF: Lipase entrapment in PVA/Chitosan biodegradable film for reactor coatings. Materials Science and Engineering C 2013, 33:1696-1701.

2. Fernandes KF, Lima CS, Lopes FM: Técnicas de Imobilização de Enzimas. Revista Processos Químicos 2010, 53-58.

3. Silva FEF, Di-Medeiros MCB, Batista KA, Fernandes KF: PVA/Polysaccharides Blended Films: Mechanical Properties. Journal of Materials 2013, 2013:6.

doi:10.1186/1753-6561-8-S4-P217

Cite this article as: Moreira et al: Imobilization of trypsin in films of PVA/CGP. BMC Proceedings 2014 8(Suppl 4):P217.

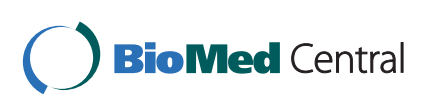

(C) 2014 Moreira et al: licensee BioMed Central Ltd. This is an Open Access article distributed under the terms of the Creative Commons Attribution License (http://creativecommons.org/licenses/by/4.0), which permits unrestricted use, distribution, and reproduction in any medium, provided the original work is properly cited. The Creative Commons Public Domain Dedication waiver (http:// creativecommons.org/publicdomain/zero/1.0/) applies to the data made available in this article, unless otherwise stated. 